\title{
Consequences of Applying Cataloguing Codes for Author Entries to the Spanish National Library Online Catalogs
}

\author{
R. Ruiz-Perez
}

\begin{abstract}
In this empirical study of a sample of catalog records I investigate the implications for information retrieval of the rules for choosing author access points in online catalogs. Aims: To obtain data that can be used to inform a revision of current cataloguing rules, and to propose more functional criteria aimed at improving the retrieval of information located on the basis of author names. Material and methods: A total of 838 records from the Biblioteca Nacional Española (Spanish National Library) were examined to analyze the use of authorities as access points. Authors were classified as creative or non-creative to facilitate the analysis. The variables investigated were author source location, potential author access points, actual entries used in the record, and loss of potential entry points. Results: A total of 3566 potential author access points were identified (mean of 4.25 per record). The title page yielded $57.3 \%$ of all potential access points, the table of contents yielded $33.5 \%$, and other sources accounted for the remaining $9.1 \%$. A total of 2125 potential authors were not used as access points in the records (overall loss of $59.5 \%)$. A total of 960 authors named on the title page were not used as entries (30.23\% loss). In works with up to three authors per responsibility function, $24.8 \%$ of the authors were not used as entry points. In works with more than three authors, $75.2 \%$ of the potential access points were unused. Discussion and conclusions: A significant proportion of potential ac-
\end{abstract}

R. Ruiz-Perez, PhD, is Professor, Department of Library and Information Science, School of Library and Information Science, University of Granada, E-18071 Granada, Spain.

Address correspondence to: R. Ruiz-Perez, Departamento de Biblioteconomía y Documentación, Campus de Cartuja, E-18071 Granada, Spain (E-mail: rruiz@ugr.es). The author would like to thank K. Shashok for translating the manuscript into English.

Cataloging \& Classification Quarterly, Vol. 32(3) 2001

(C) 2001 by The Haworth Press, Inc. All rights reserved. 
cess points from the table of contents and the title page went unused. If the access points from these sources were used, author indexes would be more complete and accurate, and retrieval with online catalogs would be more efficient. I suggest that losses for creative authors were caused by neglect of the table of contents as a source of entries, strict application of the rule of three, and other specific factors. Losses for non-creative authors were caused by ambiguities and gaps in current cataloguing rules for choosing added author entries. The findings support the urgent need to revise cataloguing rules for author access points to make them more flexible, more practical, and more in line with actual responsibility functions and types of authorship. [Article copies available for a fee from The Haworth Document Delivery Service: 1-800-342-9678. E-mail address: <getinfo@haworthpressinc.com>Website: <http://www.HaworthPress.com> () 2001 by The Haworth Press, Inc. All rights reserved.]

KEYWORDS. Revison of cataloguing rules, computerized cataloguing, online cataloguing, author access points, empirical study, choice of access points, loss of access points, cataloguing by author name, AACR2, Reglas de Catalogación Españolas, RCE, catalog of Biblioteca Nacional Española, catalog of Spanish National Library

\section{INTRODUCTION}

The appearance of computerized systems for use in library and information science led to misplaced speculations regarding new forms of information retrieval. It was claimed that pertinent bibliographic information contained in a given catalog would become rapidly accessible regardless of the internal structure. This implied a decrease in the importance of cataloguing standards, and led some to predict their imminent disappearance. However, it was soon realized that computerization increased, rather than diminished, the need for standards $;{ }^{1}$ moreover, inconsistencies in records had serious consequences, impairing accessibility and leading to loss of relevant information. ${ }^{2}$ As several authors have pointed out, 3,4 uniformity and coherence in the content of the records are indispensable to ensure the quality of bibliographic databases; hence rules for the construction and maintenance of these records remain as necessary as ever, if not more so.

From a functional perspective, however, the current standards require urgent revision and updating in consonance with the changes the tasks that online catalogs can perform. The proposals for revising standards for data format and structure have centered on increasing compatibility, simplifying the form and content of records ${ }^{5,6}$ and enhancing authority files. ${ }^{7}$ The inflexibility and 
conservativism of the hierarchical and hence constraining principles of current cataloguing codes have also been criticized. ${ }^{8,9}$

One element of cataloguing rules most in need of revision are the criteria for choosing access points, which have remained essentially unchanged through successive editions of the rules. A more functional approach is needed to apply these rules to online catalogs, designed, as some authors have noted, to function as much more flexible retrieval tools than their manual predecessors could ever be. ${ }^{10,11}$

Since the 1980s, many studies have emphasized the need to change the standards used to create bibliographic records, i.e., the ISBDs, the Cataloguing Rules, and the MARC formats. Studies that have examined the Anglo-American Cataloguing Rules (hereafter AACR2) have noted the deficiencies in this code with regard to defining and choosing access points. Analyses of the conceptual and normative framework, ${ }^{12,13,14}$ studies of the actual application of the rules, ${ }^{15,16}$ and statistical and comparative analyses of access points for specific samples of records and collections ${ }^{17,18}$ have identified four issues in need of resolution: (1) the irrelevance for computerized catalogs of the principles that underlie current cataloguing rules, (2) the need to simplify the intellectual work needed to decide which criteria to follow in choosing access points, (3) the potential for endowing catalogs with a greater number of access points, and (4) the need to base cataloguing on logical procedures and evidence-based decisions.

There have been attempts to design procedures for the automated selection of access points, ${ }^{19,20}$ and to develop expert systems for fully automated cataloguing. ${ }^{21,22}$ However, the recent appearance of online public access catalogs (OPACs) and the cataloguing of Internet sources have reoriented current research. The huge number of proposals and working documents (available on the World Wide Web) that have been generated by the revision of the AACR2 makes it difficult to summarize the current status. Among the most significant proposals are those of the Committee on Cataloguing: Description \& Access, developed by the American Library Association, ${ }^{23}$ the documents of the Joint Steering Committee for Revision of Anglo-American Cataloguing Rules, ${ }^{24}$ and the material presented by the International Conference on the Principles and Future Development of AACR, Toronto, October 23-25, 1997. ${ }^{25}$

In summary, the main features of the revision of the AACR 2 currently under way are: (1) examination and reorientation of the basic principles underlying the rules, with a view to developing a more logical structure, ${ }^{26,27}$ (2) harmonization of the new ISBE(ER) with the AACR2,28,29 (3) in-depth re-examination of the mechanisms used to chose and control access points, ${ }^{30}$ and (4) work to ensure compatibility between the AACR2, the MARC format and different metadata systems used to describe electronic resources. ${ }^{31}$ The 
latest edition of the AACR2R, available in print and online 32,33 incorporates a number of updates; however, discussion and debate continue on many fronts.

In Spain the review process has had little effect on current practice or research. In this study I examine the consequences of the rules for choosing access points in online catalog information retrieval systems. I looked at a sample of bibliographic records of the Spanish National Library (Biblioteca Nacional Española, BNE) to evaluate the influence of current mechanisms for choosing author access points, and to identify ambiguities and gaps in the rules. My analysis was based on chapter 14 of the 1995 edition of the Spanish Cataloguing Rules (Reglas de Catalogación Españolas, hereafter RCE), ${ }^{34}$ and to some extent on chapter 21 of the AACR2, ${ }^{35}$ in view of the similarities between the two codes and their widespread use in Spanish libraries.

\section{MATERIAL AND METHODS}

\subsection{Sample}

The sample consisted of 838 records from the Bibliografia Nacional Española database (CD-ROM edition with Online Computer System software). This database contains more than 300,000 records of monographs and similar publications (collections, official publications, congress proceedings, etc.) from the BNE and catalogued between 1976 and 1994. Because the earliest use of the RCE and AACR2 in Spain dates from 1985, records from earlier years were not included in the study sample. No restrictions on language or country of publication were applied.

The following procedure was used to select the sample (see Table 1):

1. Twenty-nine topic groups (TG) that represented different disciplines/areas of knowledge covered by the database were established. Items were searched for using each TG as the search term. The terms were truncated on the right and combined with the 'OR' operator.

2. The number of records retrieved in each TG was recorded (R TG), and the percentage of each group in the whole sample was calculated with the formula $\% \mathrm{TG}=(\mathrm{R} \mathrm{TG} \times 100) / \mathrm{N}$, in which $\mathrm{N}=83,845$ (total number of records retrieved in 29 searches).

3. Sample size was set at $1 \%$ of $N(n=838$ records). The estimated error was $\pm 4 \%$ for a population approaching 100,000 .

4. The percentage of each TG was converted to a number of records with the formula $X=(\% \mathrm{TG} \times 838) / 100$, where $X$ is the number of actual records for each TG in the sample. 
5. Records were located by systematic random sampling. They were saved to MARC format for exportation and manipulated in the BRS/Search program. All data and their graphic presentations were processed with Excel under Windows 98.

\subsection{Analysis of Author Access Points}

The procedure used to calculate the number and distribution of author access points did not distinguish between main and secondary headings, and allowed for all authors involved in a work to be used as entries. In other words, the criteria set forth in the cataloguing rules for main entry, the rule of three and the title page as the only source of access points were ignored.

Many proposals to abolish these criteria have been published in specialized sources. With regard to the main entry, most authors agree that this principle complicates the text of the rules, does not favor simplification of cataloguing procedures, and is irrelevant for online catalogs. ${ }^{36,37,38}$

With regard to the rule of three and the preeminence of the title page as the source of entries, Boll ${ }^{39}$ observed that many authors (especially coauthors and collaborators) involved in works that made up a large proportion of holdings were ignored as a result of over-emphasis on these elements. Svenonius, Baughman and Molto ${ }^{40}$ noted that in a computerized environment it should be possible to go beyond the rule of three and the title page to obtain additional access points. Brunt ${ }^{41}$ noted that eliminating the rule of three could improve retrieval by forcing cataloguers to create legitimate entries under names other than those that appear most prominently on the title page. Lin $^{42}$ suggested that all main authors should be used as catalog entries, and asked why three authors should be used, rather than two, four, five, or even more. Does appearance at the head of the list of authors on the title page mean that this particular author's contribution was greater, or that the name is better known? In this respect, the criteria for online catalogs should evolve, just as databases such as Medline, ${ }^{43,44}$ or Science Citation Index ${ }^{45}$ have done.

The method of analysis used in this study is based on the following hypothesis: Any author name associated with a work, regardless of its location in the work, is a potentially useful access point for the bibliographic record. This hypothesis is in consonance with some precepts that have been developed by researchers at the University of California (UCLA) interested in an empirical set of criteria that could be used to revise the AACR2. ${ }^{46,47,48}$ However, not all author names associated with a work are useful access points for retrieval, because not all persons were intellectually or materially responsible for the work. Therefore the notion of each name as an access point is not an operative general rule for cataloguing. Nevertheless, it does contain, in my view, logical cri- 
TABLE 1. Topic Groups (TG), Number of Records Retrieved per TG (R TG), Percentage of Each TG in the Sample (\%TG) and Number of Records in Each TG in the Sample $(X)$

\begin{tabular}{|c|c|c|c|c|}
\hline \multicolumn{2}{|l|}{ TG } & \multirow{2}{*}{$\begin{array}{r}\mathrm{R} T \mathrm{TG} \\
878\end{array}$} & \multirow{2}{*}{\begin{tabular}{r|r|}
$\% \mathrm{TG}$ \\
1,05
\end{tabular}} & \multirow{2}{*}{$\frac{x}{9}$} \\
\hline 1 & $\begin{array}{l}\text { Administración/pública/central/local/municipal/ } \\
\text { autonómica/provincial/institucional }\end{array}$ & & & \\
\hline 2 & Agricultura/agronomía/horticultura/silvicultura/zootécnia & 1.005 & 1,20 & 10 \\
\hline 3 & Antropología/etnología/folklore/costumbres & 816 & 0,97 & 8 \\
\hline 4 & $\begin{array}{l}\text { Arqueología/prehistoria/excavaciones arqueológicas/restos } \\
\text { arqueológicos/yacimientos arqueológicos }\end{array}$ & 557 & 0,66 & 6 \\
\hline 5 & Arte/arquitectura/escultura/pintura/fotografía/diseño & 8.240 & 9,83 & 82 \\
\hline 6 & Astronomía/astrofísica/geodesia/cosmografía/cosmología & 431 & 0,51 & 4 \\
\hline 7 & $\begin{array}{l}\text { Biología/ciencias naturales/zoología/botánica/biofísica } \\
\text { /bioquímica/citología/microbiología }\end{array}$ & 3.296 & 3,93 & 33 \\
\hline 8 & Derecho/jurisprudencia/justicia & 3.759 & 4,48 & 37 \\
\hline 9 & Deportes/atletismo/educación física & 635 & 0,76 & 7 \\
\hline 10 & $\begin{array}{l}\text { Documentación/biblioteconomía/bibliotecas/información } \\
\text { científica/archivos }\end{array}$ & 412 & 0,49 & 5 \\
\hline 11 & Economía/economía y política/macroeconomía/microeconomía & 1.778 & 2,12 & 18 \\
\hline 12 & Filosofía/metafísica/ética/lógica & 2.079 & 2,48 & 21 \\
\hline 13 & Física/mecánica/acústica/óptica/termodinámica/electricid. & 2.220 & 2,65 & 22 \\
\hline 14 & $\begin{array}{l}\text { Geografía/demografía/climatología/geomorfología/ } \\
\text { hidrografía/ biogeografía /ecología }\end{array}$ & 1.480 & 1,77 & 15 \\
\hline 15 & $\begin{array}{l}\text { Geología/cristalografía/mineralogía/hidrología/meteorología/ } \\
\text { petrología/recursos naturales }\end{array}$ & 783 & 0,93 & 8 \\
\hline 16 & Historia (Key Word in title) & 9.070 & 10,82 & 90 \\
\hline 17 & Industria/desarrollo industrial/empresas/comercio & 3.356 & 4,00 & 34 \\
\hline 18 & $\begin{array}{l}\text { Informática/datos-tratamiento electrónico/información- } \\
\text { sistemas/ordenadores/telemática }\end{array}$ & 765 & 0,91 & 8 \\
\hline 19 & Ingeniería/tecnología/electrotecnia & 1.006 & 1,20 & 10 \\
\hline 20 & Lingüística/Filología/lengua/lenguaje/gramática/semiótica & 9.347 & 11,15 & 93 \\
\hline 21 & $\begin{array}{l}\text { Literatura/teatro/poesía/novela/cuentos/literatura infantil/ } \\
\text { Creación literaria/crítica literaria }\end{array}$ & 7.372 & 8,79 & 73 \\
\hline 22 & $\begin{array}{l}\text { Matemáticas/aritmética/álgebra/geometría/estadística/análisis } \\
\text { matemático/cálculomatemático/análisis combinatorio }\end{array}$ & 5.464 & 6,52 & 54 \\
\hline 23 & $\begin{array}{l}\text { Medicína/farmacología/anatomía/fisiología/higiene/medicamentos/ } \\
\text { patología/cirujía/ginecología/oftalmología/cardiología/pediatría/ } \\
\text { neurología/endocrinología/psiquiatría }\end{array}$ & 3.917 & 4,67 & 39 \\
\hline 24 & Pedagogía/educación/didáctica/enseñanza & 6.238 & 7,44 & 62 \\
\hline 25 & Psicología/psicoterapia & 2.082 & 2,48 & 21 \\
\hline 26 & Política/instituciones políticas/regímenes políticos & 1.434 & 1,71 & 15 \\
\hline 27 & $\begin{array}{l}\text { Química/bioquímica/análisis químico/compuestos químicos } \\
\text { /industria química }\end{array}$ & 1.840 & 2,19 & 18 \\
\hline 28 & Sociología & 483 & 0,58 & 5 \\
\hline 29 & Religión/teología/iglesia/biblia & 3.102 & 3,70 & 31 \\
\hline Tot & & 83.845 & 99,99 & 838 \\
\hline
\end{tabular}


teria for an analysis of author access points that make it possible to analyze the functionality of the rules in computerized contexts.

To restrict this analysis to those authors that are useful for purposes of retrieval, I propose a system of categorization based on the degree of responsibility of each author for the work. The proposed system makes it possible to distinguish between names that are important and those that are not. The system was developed in three stages, as detailed below:

Stage 1. Among all author names, both personal and corporate, involved in a publication, two groups are distinguished: those authors related with intellectual or artistic content, and authors related with the material production, publication, etc., of the work. The first group is the main source of author entries in catalogs. Of the names in the second group only that of the publisher can be considered useful.

Stage 2. The first group is subdivided into (1) those authors who made a significant contribution to the content in the form of original contributions, or who added or modified content, and (2) auxiliary authors or those whose contributions did not modify the content but rather used the content to create a derived document or part of a document. The problem is to distinguish between the two types within a given work, on the basis of the terms (responsibility functions) associated with each name. This is done with the aid of an authorship taxonomy (see Appendix 1 and Ruiz-Pérez ${ }^{49}$ ).

Stage 3. The different types of authorship are categorized as creative or non-creative ${ }^{50}$ according to the author's importance for the creation of the work.

\subsection{Analysis of the Records}

The records were analyzed for the following variables:

1. Source location of the author access points, recorded as title page, other source (cover, preliminary matter, copyright page) or table of contents (when the authors' names are given).

2. Potential access points: the presence in any location of author names that are potentially usable as access points.

3. Used access points: author entries actually used in the record.

4. Unused access points: the difference obtained by subtracting used access points from potential access points.

The procedure used to record and analyze the data was as follows:

1. To assign authors to locations, I followed the recommendations of the ISBD. Authors whose names appear in brackets in the MARC 245 \$c field 
were assigned to other sources. When the record described a collection of works or parts of works under a collective title, the authors in field 505 \$a were recorded as appearing on the title page. When the $505 \$$ a field identified a collaborative work among different authors associated with different contributions, the table of contents was used to determine location of the author access points. This approach was used for congress proceedings (for example), in which the authors of each plenary and communication appeared in the table of contents. If none of the three situations described above applied, the authors were assumed to be identified from the title page.

2. To calculate the potential access points I checked the MARC fields not defined as access points but that might contain author names: 245 \$c, $260 \$ b$, $500 \$ a, 502 \$ a$ and $505 \$ a$. To record data that would otherwise have required examination of the original document I used information available in the records. This was necessary in two situations: (1) when the record included the abbreviation "et al." after a name, and (2) in records of congress proceedings. In the former case I examined a random sample of 50 monographs for which more than three authors were mentioned as having responsibility functions; this yielded a mean of 4.7 authors per use of the "et al." abbreviation. In the latter case I used the same procedure with a sample of 27 congress proceedings, and found a mean of 47.8 authors per publication.

3. To calculate the access points actually used, I counted the MARC fields defined as author access points: 101, 110, 111, 700, 710 and 711. The main difficulty was in assigning authors to a given type of authorship; this was the result of the lack of standardization in the \$e subfield (Reporter) of the 7XX fields. An automatic count would have produced spurious data, so the records were checked manually.

\section{RESULTS}

\subsection{Potential Access Points}

When all possible locations of authors were considered, a total of 3566 author names were found in the works represented in the records I sampled (mean of 4.25 authors per work, see Table 2). On the basis of the categories proposed here, the distribution of authors by category and the type of authorship, $72.4 \%$ were creative authors, most of whom (66.7\%) had sole or shared responsibility (auth-coaut. and coll.). In contrast, corporate authors, congress proceedings and mixed responsibilities comprised only $5.7 \%$ of the author names found. Non-creative authors, including publishers, accounted for $27.6 \%$ of the names.

When authors from the table of contents were excluded, the distribution was markedly different (Table 2). For a total of 2371 authors, the mean number 
TABLE 2. Number and Distribution of Potential Authors per Category, Type of Authorship and Location

\begin{tabular}{|c|c|c|c|c|c|c|}
\hline \multirow[t]{2}{*}{ Category } & \multirow{2}{*}{$\begin{array}{l}\text { Type } \\
\text { of authorship }\end{array}$} & \multicolumn{3}{|c|}{ Source location } & \multirow[t]{2}{*}{$\%$} & \multirow[t]{2}{*}{$\%$} \\
\hline & & TP & os & T C & & \\
\hline \multirow{4}{*}{$\begin{array}{l}\text { Creative authors } \\
\text { (Shared } \\
\text { responsibility) }\end{array}$} & Auth-coaut. & 1008 & 70 & 44 & 31.46 & 45.47 \\
\hline & Coll. & 162 & 0 & 1095 & 35.25 & 6.83 \\
\hline & Corp. Body & 142 & 5 & 1 & 4.15 & 6.20 \\
\hline & Congr. & 34 & 6 & 0 & 1.12 & 1.69 \\
\hline \multirow{2}{*}{$\begin{array}{l}\text { Creative authors } \\
\text { (Mixed } \\
\text { responsibility) }\end{array}$} & Adp. & 13 & 1 & 0 & 0.39 & 0.59 \\
\hline & Cont. & 1 & 0 & 0 & 0.03 & 0.04 \\
\hline \multirow{8}{*}{$\begin{array}{l}\text { Non-creative } \\
\text { authors, important } \\
\text { functions }\end{array}$} & Annot. & 17 & 6 & 0 & 0.64 & 0.97 \\
\hline & Edt-com. & 113 & 19 & 3 & 3.79 & 5.57 \\
\hline & Drt.-coord. & 93 & 17 & 3 & 3.17 & 4.64 \\
\hline & Comp. & 9 & 1 & 0 & 0.28 & 0.42 \\
\hline & $\mathrm{Cmm}$ & 36 & 2 & 1 & 1.09 & 1.60 \\
\hline & III. & 37 & 25 & 12 & 2.08 & 2.61 \\
\hline & Trl. & 95 & 153 & 10 & 7.23 & 10.46 \\
\hline & Rd-nrt & 6 & 20 & 26 & 1.46 & 1.10 \\
\hline \multirow{2}{*}{$\begin{array}{l}\text { Non-creative } \\
\text { authors, auxiliary } \\
\text { functions }\end{array}$} & Pr. & 36 & 1 & 0 & 1.04 & 1.56 \\
\hline & Wam. & 2 & 0 & 0 & 0.06 & 0.08 \\
\hline $\begin{array}{l}\text { Publication } \\
\text { functions }\end{array}$ & Pbl. & 241 & 0 & 0 & 6.76 & 10.16 \\
\hline \multicolumn{2}{|l|}{ Total } & 2045 & 326 & 1195 & 100 & 100 \\
\hline \multicolumn{2}{|c|}{ Total potential all Sources } & \multicolumn{3}{|c|}{$2045+326+1195=3566$} & --- & --- \\
\hline \multicolumn{2}{|c|}{ Total potential excluding TC } & \multicolumn{2}{|c|}{$2045+326=2371$} & & & \\
\hline
\end{tabular}

TP, Title page; OS, Other sources; TC, Table of contents.

$\%$ Percent of all data; \% Percent excluding TC

of authors per work was 2.82 . The proportion of creative authors (60.8\%) was $11.6 \%$ percentage points lower than when all author names were considered, and non-creative authors (39.2\%) made up a larger proportion of the number of authors.

A comparison of these two sets of data revealed a considerable decrease in the number of collaborators (from $35.6 \%$ to $6.8 \%$ ) when authors located from the table of contents were excluded, and the low proportion of corporate authors and congress proceedings among creative authors (4.2\%-6.2\% and $1.1 \%-1.7 \%$, respectively). The contribution of mixed responsibilities (adaptations, continuations, writer + artist collaborations, reports, interviews, texts accompanied by bibliographic or critical material, etc.), many of which were not represented in the sample, was negligible $(0.4 \%-0.6 \%)$.

The results for non-creative authors also varied widely between the data for all author names found and the number when authors from the table of contents 
were excluded. Three types of authorship were common (translators 7.2\%-10.5\%, editor-compiler and director-coordinator 7.0\%-10.2\%). However, other types of authorship were rare in the total group of potential authors. Publishers made up $6.8 \%$ of the total number of potential authors, and $10.2 \%$ of the authors when names obtained from the table of contents were excluded. This result is noteworthy in view of the fact that only official, religious, international or governmental organisms with publishing functions were considered in this subgroup.

\subsection{Location of Potential Author Access Points}

Of the total of 3566 authors, the largest proportion (2045) were identified from information on the title page (Table 2). The proportion of creative authors $(66.5 \%)$ was twice as high as that of non-creative authors (33.5\%). However, when all locations were considered together the title page accounted for only slightly more than half of all authors identified (57.34\%) (see Figure 1). The other 1521 authors were located from the table of contents $(1195,33.51 \%)$ and from other sources $(326,9.14 \%)$.

The large contribution of the table of contents and other sources led me to analyze in detail the types of authorship associated with sources of information other than the title page, in order to identify which categories these authors belonged to. Potential author access points located in parts of the document outside the title page are likely to be overlooked by cataloguers, and hence to remain unused as entries in catalog indexes.

Figure 2 illustrates that the type of author most frequently identified from the table of contents was creative authors, especially collaborators $(91.6 \%$ of

FIGURE 1. Distribution of Potential Author Access Points According to Source of Information

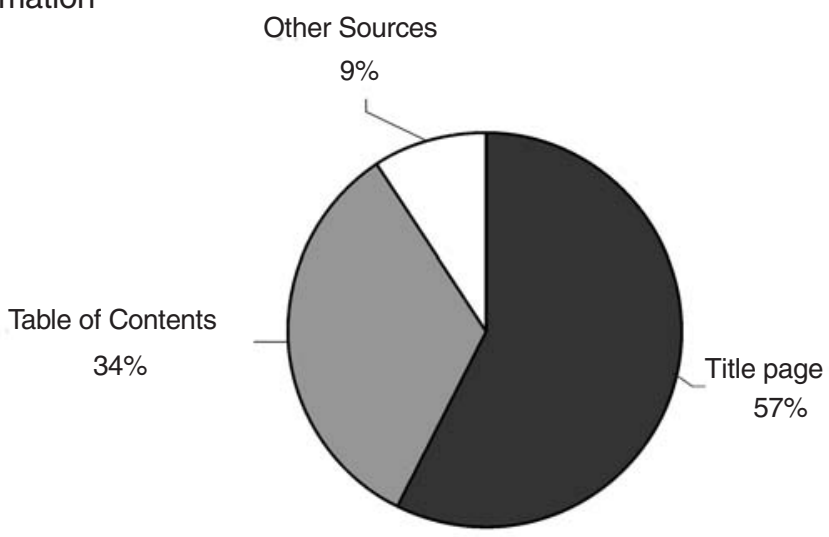


FIGURE 2. Distribution of Potential Authors in the Table of Contents and Other Sources

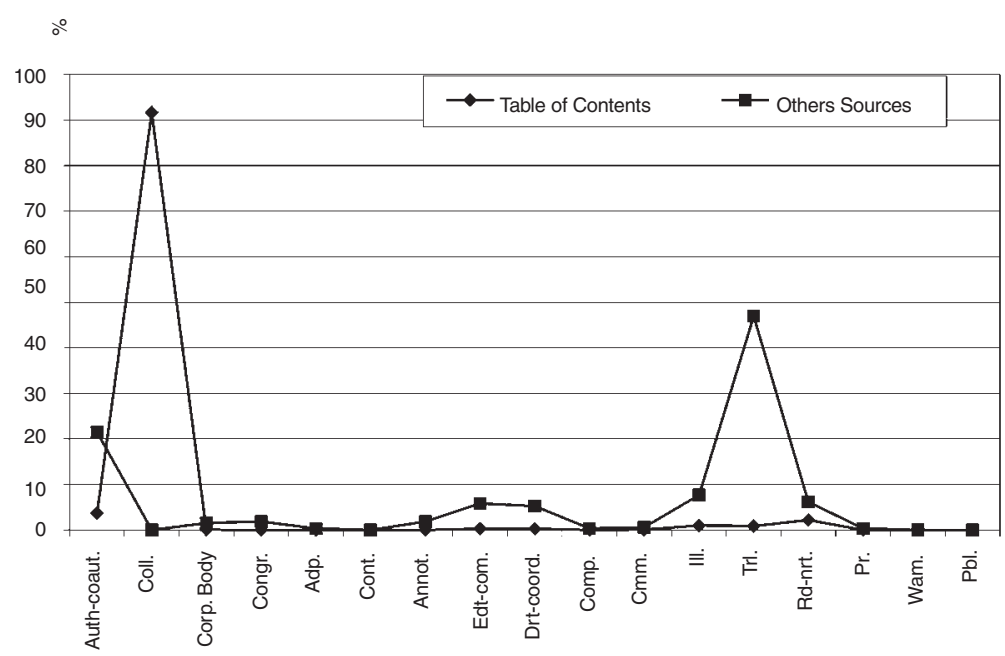

1195). For other types of authorship, this source was unproductive. Of the 326 names located from other sources, $21.5 \%$ were authors or coauthors, and the rest were non-creative authors such as translators (46.9\%), illustrators (7.7\%), editors-compilers (5.8\%) and directors-coordinators (5.2\%).

\subsection{Loss of Access Points}

The number of overlooked (lost) access points (L) was calculated by subtracting the actual number of author entries in the records (U) from the number of author names potentially usable as entries (P). Table 3 shows that for all locations, only 1441 entries were included in the records, in contrast with a total of 3566 potential authors. Therefore 2125 author entries (59.6\%) were lost. Of this number, $74.2 \%$ belonged to the category of creative authors $(57.2 \%$ collaborators, $15.8 \%$ coauthors, $1.2 \%$ others); the remaining $25.8 \%$ were non-creative authors.

\subsubsection{Influence of Excluding the Table of Contents as a Source Location}

The distribution of author categories was different when the table of contents location was excluded, since this location provided a large number of potential authors (1195) but only 33 actual entries. Of the 2371 potential authors identified from the title page and other sources, 1408 were used as actual entries; 
TABLE 3. Loss of Author Access Points According to Category, Type of Authorship and Location

\begin{tabular}{|c|c|c|c|c|c|c|c|}
\hline \multirow[t]{2}{*}{ Category } & \multirow{2}{*}{\begin{tabular}{|l|} 
Type of \\
authorship
\end{tabular}} & \multicolumn{3}{|l|}{ All sources } & \multicolumn{3}{|c|}{ Excluding Table of contents } \\
\hline & & $P$ & $\mathrm{u}$ & $\% \mathrm{~L}$ & $\mathrm{P}$ & $\mathrm{U}$ & $\% L$ \\
\hline \multirow{6}{*}{$\begin{array}{l}\text { Creative authors, } \\
\text { Shared and } \\
\text { mixed } \\
\text { responsibility }\end{array}$} & Auth-coaut. & 1122 & 785 & 15.8 & 1078 & 777 & 31.26 \\
\hline & Coll. & 1257 & 41 & 57.2 & 162 & 26 & 14.1 \\
\hline & Corp. Body & 148 & 131 & 0.80 & 147 & 130 & 1.77 \\
\hline & Congr. & 40 & 35 & 0.24 & 40 & 35 & 0.52 \\
\hline & Adp. & 14 & 11 & 0.14 & 14 & 11 & 0.31 \\
\hline & Cont. & 1 & 1 & 0 & 1 & 1 & 0 \\
\hline \multirow{8}{*}{$\begin{array}{l}\text { Non-creative } \\
\text { authors, } \\
\text { important } \\
\text { functions }\end{array}$} & Annot. & 23 & 9 & 0.66 & 23 & 9 & 1.45 \\
\hline & Edt-com. & 135 & 76 & 2.78 & 132 & 75 & 5.92 \\
\hline & Drt.-coord. & 113 & 56 & 2.68 & 110 & 55 & 5.71 \\
\hline & Comp. & 10 & 3 & 0.33 & 10 & 3 & 0.73 \\
\hline & $\mathrm{Cmm}$ & 39 & 20 & 0.89 & 38 & 20 & 1.87 \\
\hline & IIII. & 74 & 37 & 1.74 & 62 & 31 & 3.22 \\
\hline & Trl. & 258 & 79 & 8.42 & 248 & 78 & 17.6 \\
\hline & Rd-nrt & 52 & 12 & 1.88 & 26 & 12 & 1.45 \\
\hline \multirow{2}{*}{$\begin{array}{l}\text { Non-creative } \\
\text { authors, } \\
\text { auxiliary } \\
\text { functions } \\
\end{array}$} & Pr. & 37 & 24 & 0.61 & 37 & 24 & 1.35 \\
\hline & Wam. & 2 & 1 & 0.05 & 2 & 1 & 0.10 \\
\hline $\begin{array}{l}\text { Publication } \\
\text { functions }\end{array}$ & Pbl. & 241 & 120 & 5.69 & 241 & 120 & 12.5 \\
\hline \multicolumn{2}{|l|}{ Total } & 3566 & 1441 & 99.91 & 2371 & 1408 & 99.86 \\
\hline \multicolumn{2}{|l|}{ Total $\mathrm{P}-\mathrm{U}$} & \multicolumn{3}{|c|}{$3566-1441=2125$} & \multicolumn{3}{|c|}{$2371-1408=963$} \\
\hline
\end{tabular}

$\mathrm{P}$, potential; $\mathrm{U}$, used; \%L, percent of the total that were lost

therefore, the proportion of lost access points corresponding to the 963 unused names was $59.4 \%$ (Table 3). Of this number, $47.96 \%$ were creative authors (31.3\% coauthors, $14.1 \%$ collaborators, $2.6 \%$ others). Among non-creative authors the proportion of lost access points was larger (51.9\%), and comprised translators (17.6\%), publishers (12.5\%), editors-compilers (5.9\%) and directors-coordinators (5.7\%).

Because the table of contents played an important role in the loss of entries, further analyses were aimed at characterizing the problem in detail, and at determining how rules other than those related with criteria for including or excluding source locations also influenced the loss of entry points in catalogs. I therefore analyzed separately the data for each of the three source locations (see Table 4). The percentage of lost entries (see Figure 3) was compared with the formula $\% \mathrm{~L}=(\mathrm{P}-\mathrm{U}) \times 100 / \mathrm{P}$, which represents the ratio of potential access points to the number of access points actually used in the records. To sim- 
TABLE 4. Loss of Author Access Points According to Type of Authorship and Location (Absolute Values and Percent for Each Type of Authorship)

\begin{tabular}{|c|c|c|c|c|c|c|c|c|c|}
\hline \multirow{2}{*}{$\begin{array}{l}\text { Type of } \\
\text { authorship }\end{array}$} & \multicolumn{3}{|l|}{ Title page } & \multicolumn{3}{|c|}{ Other sources } & \multicolumn{3}{|c|}{ Table of contents } \\
\hline & $\mathrm{P}$ & U & $\% \mathrm{~L}$ & $\mathrm{P}$ & $\mathrm{U}$ & $\% \mathrm{~L}$ & $\mathrm{P}$ & $U$ & $\% \mathrm{~L}$ \\
\hline Auth-coaut. & 1.008 & 745 & 26.09 & 70 & 32 & 54.28 & 44 & 8 & 81.81 \\
\hline Coll. & 162 & 26 & 83.95 & 0 & 0 & 0 & 1095 & 15 & 98.63 \\
\hline Body-Cong. & 174 & 159 & 8.62 & 13 & 6 & 53.84 & 1 & 1 & 0 \\
\hline Adp. & 13 & 11 & 15.38 & 1 & 0 & 100 & 0 & 0 & 0 \\
\hline Cont. & 1 & 1 & 0 & 0 & 0 & 0 & 0 & 0 & 0 \\
\hline Annot. & 17 & 8 & 52.94 & 6 & 1 & 83.33 & 0 & 0 & 0 \\
\hline Edt-com. & 113 & 68 & 39.82 & 19 & 7 & 63.15 & 3 & 1 & 66.66 \\
\hline Drt.-coord. & 93 & 50 & 46.23 & 17 & 5 & 70.58 & 3 & 1 & 66.66 \\
\hline Comp. & 9 & 2 & 77.77 & 1 & 1 & 0 & 0 & 0 & 0 \\
\hline $\mathrm{Cmm}$ & 36 & 19 & 47.22 & 2 & 1 & 50 & 1 & 0 & 100 \\
\hline III. & 37 & 16 & 56.65 & 25 & 15 & 40 & 12 & 6 & 50 \\
\hline Trl. & 95 & 33 & 65.26 & 153 & 45 & 70.58 & 10 & 1 & 90 \\
\hline Rd-nrt & 6 & 1 & 83.33 & 20 & 11 & 45 & 26 & 0 & 100 \\
\hline Pr. & 36 & 24 & 33.33 & 1 & 0 & 100 & 0 & 0 & 0 \\
\hline Wam. & 2 & 1 & 50 & 0 & 0 & 0 & 0 & 0 & 0 \\
\hline Pbl. & 241 & 120 & 50.20 & 0 & 0 & 0 & 0 & 0 & 0 \\
\hline Total & 2043 & 1284 & - & 328 & 124 & - & 1195 & 33 & - \\
\hline PT $P-U$ & \multicolumn{2}{|c|}{$2043-1284=759$} & $35.7 \%$ & \multicolumn{2}{|c|}{$328-124=204$} & $9.6 \%$ & \multicolumn{2}{|c|}{$1195-33=1162$} & $54.6 \%$ \\
\hline
\end{tabular}

$P$, potential; $U$, used; L, loss; PT P $-U$, partial total minus used; TP $-U$, total potential minus used; $\% L=(P-U) \times 100 / P$; $\%=(P T P-U) \times 100 / T P-U$

plify the presentation of the findings I ranked the results in increasing order and excluded authorship types that provided between 0 and 3 potential access points.

Of the total number of lost entries $(\mathrm{P}-\mathrm{U}=2125)$, the distribution among source locations was $54.7 \%$ from the table of contents, $35.7 \%$ from the title page, and $9.6 \%$ from other sources. Nearly all different types of authorship were among those lost from the title page, although the proportions of different types varied widely. Creative authors were lost relatively infrequently (corporate body-congress proceedings $8.6 \%$, author-coauthor $26.1 \%$ ), with the notable exception of collaborators (83.9\%). Among non-creative authors, losses were much higher, although again the percentages varied widely (authors of prologues $33.3 \%$, redactor-narrators $83.3 \%$ ). In other locations the pattern of lost access points was similar to that found for the title page, although the number of potential authors supplied by other locations was much smaller. A notable exception was translators, for whom a large number of potential access points were lost. 
FIGURE 3. Loss of Author Access Points According to Source Location and Type of Authorship

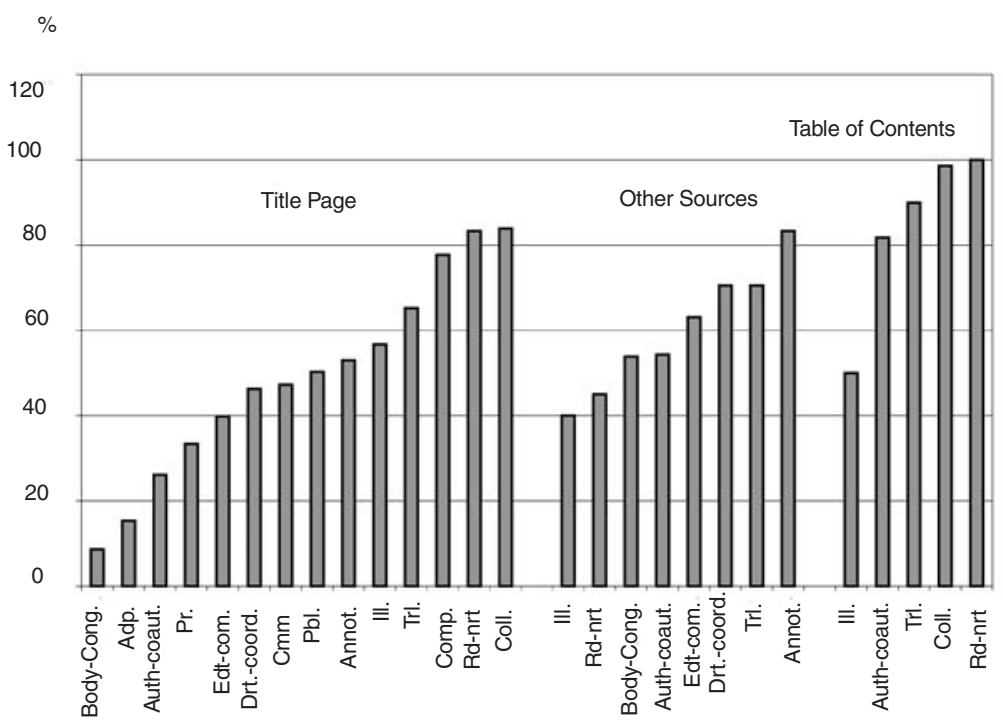

The large numbers of potential access points that were overlooked from the information in the table of contents were concentrated in only a few types of authorship, mainly in the creative authorship category (authors-coauthors $81.8 \%$, collaborators $98.6 \%$ ). In the non-creative category, the few potential author access points lost from this location represented only three types of author (illustrator, translator and redactor-narrator) (Table 4). Other types of potential authors were not identified in this location; hence, no losses were detected.

The most significant findings were the large number of potential entries for creative authors which were lost from the title page and table of contents (26.1\%-81.8\% coauthors, $83.9 \%-98.6 \%$ collaborators), and the large number of potential entries for non-creative authors lost from the title page. Of particular concern was that the types of authorship being overlooked were among the most common in modern monographs, i.e., translators (66.5\%), illustrators (56.6\%), publishers $(50.2 \%)$, directors-coordinators $(46.2 \%)$ and editors-compilers $(39.8 \%)$.

\subsubsection{Influence of Number of Authors Under Different Responsibility Functions}

I then studied the loss of entries for creative and non-creative authors when three or fewer or more than three authors with responsibility functions were in- 
volved in the work (see Table 5). Because there were no significant differences between locations (except for the loss of a large proportion of access points for collaborators), the data for title page, table of contents and other locations were pooled to analyze the variable number of authors. The percentages of access points lost for each type of author were calculated with the formula $\% \mathrm{~L}=(\mathrm{P}-$ $\mathrm{U}) \times 100 / \mathrm{PT} \mathrm{P}-\mathrm{U}$, where PT $=$ partial total potential number of access points for each type of authorship. The losses for different types of authorship in the two groups of records are shown in Figure 4.

Of the 2125 author access points that were lost, $24.8 \%$ were from works with up to three authors and $75.2 \%$ were from works with more than three authors. Table 5 and Figure 4 show that in the group of works with more than three authors, there were no records with certain types of authorship (e.g., adapters or compiler), hence all losses for this type of authorship occurred in

TABLE 5. Loss of Author Access Points According to Type of Authorship and Mentions of Up to Three and More Than Three Authors (Absolute Values and Percent Value)

\begin{tabular}{|c|c|c|c|c|c|c|c|}
\hline \multirow{2}{*}{$\begin{array}{l}\text { Type of } \\
\text { authorship }\end{array}$} & \multicolumn{3}{|c|}{ Up to 3 statements } & \multicolumn{3}{|c|}{ More than 3 statements } & \multirow[t]{2}{*}{ PT $P-U$} \\
\hline & P & U & $\% \mathrm{~L}$ & $\mathrm{P}$ & $u$ & $\% \mathrm{~L}$ & \\
\hline Auth-coaut. & 738 & 711 & 8.01 & 384 & 74 & 91.98 & 337 \\
\hline Coll. & 93 & 26 & 5.50 & 1164 & 15 & 94.49 & 1216 \\
\hline Body-Cong. & 188 & 166 & 100 & 0 & 0 & - & 22 \\
\hline Adp. & 14 & 11 & 100 & 0 & 0 & - & 3 \\
\hline Cont. & 1 & 1 & 0 & 0 & 0 & - & 0 \\
\hline Annot. & 18 & 7 & 78.57 & 5 & 2 & 21.42 & 14 \\
\hline Edt-com. & 110 & 73 & 62.71 & 25 & 3 & 37.28 & 59 \\
\hline Drt.-coord. & 83 & 53 & 52.63 & 30 & 3 & 47.36 & 57 \\
\hline Comp. & 10 & 3 & 100 & 0 & 0 & - & 7 \\
\hline $\mathrm{Cmm}$ & 29 & 18 & 57.89 & 10 & 2 & 42.10 & 19 \\
\hline III. & 59 & 34 & 67.56 & 15 & 3 & 32.43 & 37 \\
\hline Trl. & 183 & 71 & 62.56 & 75 & 8 & 37.43 & 179 \\
\hline Rd-nrt & 52 & 12 & 100 & 0 & 0 & - & 40 \\
\hline Pr. & 37 & 24 & 100 & 0 & 0 & - & 13 \\
\hline Wam. & 2 & 1 & 100 & 0 & 0 & - & 1 \\
\hline Pbl. & 241 & 120 & 100 & 0 & 0 & - & 121 \\
\hline Total & 1858 & 1331 & & 1708 & 110 & & 2125 \\
\hline PT P - U & \multicolumn{2}{|c|}{$1858-1331=527$} & $24.8 \%$ & \multicolumn{2}{|c|}{$1708-110=1598$} & $75.2 \%$ & \\
\hline$T P-U$ & \multicolumn{7}{|c|}{$527+1598=2125$} \\
\hline
\end{tabular}

P, potential; U, used; PT P - U, partial total potential minus used for each type of authorship 
FIGURE 4. Loss of Author Access Points According to Type of Authorship in Mentions of up to Three and More than Three Authors

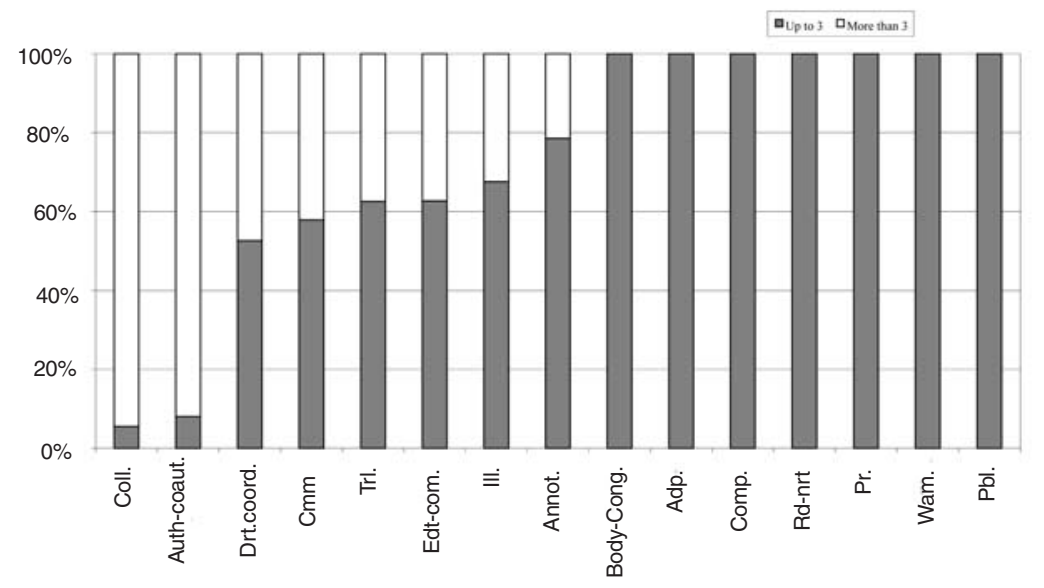

works with up to three authors. These types of authorship accounted for few potential access points (except for corporate bodies and publishers), and therefore had little influence on the results of my analysis.

Of greater interest were the findings for types of authorship that accounted for large numbers of lost access points in both groups of records. Two patterns were clearly distinguishable (Figure 4): one in which many potential access points for creative authors were lost in works with more than three authors (91.4\% coauthors, $94.4 \%$ collaborators), and another in works with up to three authors, in which losses were much smaller (coauthors $8.0 \%$, collaborators $5.5 \%$ ). For non-creative authors, in contrast, the losses of access points for directors-coordinators and annotators were greater in works with up to three authors (director-coordinator $52.6 \%$, translator $62.6 \%$, illustrator $67.6 \%$, annotator $78.6 \%$ ).

These findings show, in general, that for authors traditionally designated as "main authors," potential access points are lost when these names appear in association with multiple responsibility functions and when there are more than three authors (i.e., in works created by coauthors or collaborators). The losses for "secondary authors" were greater in works with up to three authors, although for this type of author few of the works with more than three authors contained multiple types of authorship. (In other words, a given work rarely has more than three commentators, or more than three prologues by different authors.) 


\section{DISCUSSION}

\subsection{Potential Access Points}

An analysis of potential access points shows that many authors can be involved in modern monographs; the names of all of them are potential catalog entries. Even if the names given in the table of contents are excluded (as this location is rarely considered in cataloguing codes), many potential author access points are still available. In most cases these potential access points correspond to creative (as opposed to non-creative) authors.

The data reported here suggest many topics for discussion and debate. Entries considered thus far by cataloguing rules as added entries (AACR2, p. 354; RCE, p. 427) for authors (i.e., coauthors, collaborators, directors, editors, translators, publishers, etc.) are of sufficient importance in modern monographs to deserve more rigorous consideration in the criteria for choosing access points. Winke ${ }^{51}$ has noted that an important part of the suggested revisions of the AACR2 should be to expand the criteria for choosing added entries to the main text of chapter 21. Svenonius, Baughman and Molto ${ }^{52} \mathrm{ob}-$ served that if those who developed the rules based their consideration on the actual situation with regard to authorship when the current rules were pub-

lished, the number of authors who participated in the creation of books must have been much smaller than is now the case.

The findings of the present study suggest that mixed authorships (such as adaptors, continuers, writer-artist collaborations, reports-interviews, texts accompanied by bibliographic or critical material, etc.) provide few access points. This result contrasts with the huge amounts of text that cataloguing rules devote to these types of contribution, as in sections $21.10,21.15,21.24$ and 21.25 of the AACR2 and sections 14.2.2 Ac, 14.2.2 Ad and 14.2.2 B in the RCE.

In the sample I analyzed, some non-creative authors (except for editors-compilers and directors-coordinators) also accounted for few access points. Despite the low number of potential access points for these kinds of authorship, the types of work they are usually involved in (illustrated texts, reviews, texts accompanied by commentaries, etc.) are dealt with in great detail in cataloguing rules (RCE pp. 380-383; AACR2R pp. 333-337).

The use of the publisher as an access point appears to be more common than would be expected from current rules. Although this access point is rarely used in catalogs, and the rules governing its standardization are confusing (RCE, p. 390; AACR2R, 21.30E, p. 355), publishers accounted for $6.7 \%$ to $10.16 \%$ of all potential access points in the sample of Spanish monographs I analyzed, and the publisher is currently a key element in many information retrieval processes. 


\subsection{Source Location of Access Points}

The diversification of sources of information introduced by the ISBDs was initially hailed as an innovation; however, although they break with the traditional pre-eminence of the title page, this location remains the main source of information in current cataloguing rules. In the sources for determining access points, the rules recommend the title page (AACR2R 21.0B, p. 311; RCE, p. 370), and many specific precepts repeat the condition that the access points should appear on the title page or in the main source of information. Thus the rules tend to impose the title page as the source of access points, to the detriment of other sources (e.g., preliminary matter, the copyright page, and, notably, the table of contents).

In the present analysis I found that the table of contents was a rich source of authors. More importantly, the names in the table of contents did not refer to marginal contributors, but to authors who participated in the creation of the work. These authors are collaborators in different parts of the work and different chapters in congress proceedings, i.e., in works whose title page rarely reflected the whole story with regard to the persons who made substantial contributions to the content.

\subsection{Loss of Access Points}

One of the main goals of this study was to identify deficiencies in the current rules for choosing access points, and to outline possible ways to exploit additional types of authorship for the purposes of information retrieval in computerized catalogs. This initial analysis showed that most entries were lost because of the exclusion of the table of contents from current cataloguing processes. However, this was not the only cause of neglected access points. Re-analysis of the data after excluding the data for authors identified in the table of contents showed that many potential access points were still being lost $(40.6 \%)$. Hence the location of authors' names in the work is not the only cause of the problem.

The losses of access points from the title page and other locations are probably due to the limitations imposed by some rules, the ambiguity of others, and the lack of standardized guidelines for certain cases. For coauthors, the loss of access points can be blamed on the criteria in section 14.2.2 Ab of the RCE (p. 376) and section 21.6C2 of the AACR2R (p. 327), and the recurrent use of the rule of three. The problem is the same for collaborators, covered in rules 14.2.2 Aa (p. 375) and 14.2.2 Da (p. 386-387) of the RCE, and sections 21.6B1 (p. 325) and 21.7B1 (p. 331) of the AACR2R.

The loss of access points for non-creative authors from the title page varied depending on the type of authorship. Although all types belonged to the same category and should have the same weight for the purposes of information re- 
trieval, the large variation about the mean value for different types of author $(54.79 \pm 14.15 \%)$ reflected two particular situations: a degree of anarchy in the choice of access points, and the lack of clear policies and practices that would allow cataloguers to compensate for ambiguities in the rules for added entries. There is no logical explanation for the large differences between the use of different types of secondary author as access points other than the ambiguities and conditions set down in section 14.7 of the RCE (pp. 427-428) and sections 21.29 and 21.30 of the AACR2R (pp. 354-357). By way of example the text of these rules is reproduced here:

Los traductores, ilustradores, prologuistas, etc. [serán posibles puntos de accesso] cuando se considere conveniente por la importancia de su labor o por razones de recuperación de información. (RCE, p. 428)

In addition, make an added entry under the heading for a person or a ... if some catalogue users might suppose that the description of an item would be found under that heading or title rather than under the heading or title chosen for the main entry. (AACR2R, p. 354)

However, fewer access points were lost for some types of authors belonging to the non-creative category, e.g., editor-compilers and director-coordinators. This may reflect the more specific language of sections 14.2.2 Da and 14.2.2 Db of the RCE (p. 385 and 387) and sections 21.7B1, 21.7C1 and 21.30D1 of the AACR2R (pp. 329-331 and 355). The loss of 50.2\% of the potential access points for publishers was also due to the lack of clear recommendations in sections 21.30E and 21.36A (Law Reports) in the AACR2R (pp. 355-356 and 369-370) and in the RCE, where allusions to the publisher are limited to encyclopedias and atlases known by the name of the editor and bodies that publish laws (RCE 1995, p. 390). Section 14.7 of the RCE, which deals with added entries, does not even mention publishers.

Some of these problems with the text of the AACR2 rules have been described previously. Cockshutt, Cook and Schabs ${ }^{53}$ expressed doubts about the internal logic of chapter 21 of the AACR2, and noted inconsistencies, needless rules and conceptual gaps. Meador and Wittig ${ }^{54}$ found that only 12 of the 143 rules in chapters 21 were useful for the items catalogued in a collection of economics texts, and that only 22 of the rules were useful for a collection of chemistry texts. Abrera and Shaw 55 analyzed a sample of 716 records from the Online Computer Library Center (OCLC), and found that only $31.5 \%$ of the rules were used to determine access points. Winke ${ }^{56}$ reported that a core of general rules would cover most cases in which a choice was necessary. Taniguchi ${ }^{57}$ reviewed the AACR 2 with a computerized analysis of the syntax of the text of the rules and the interrelationships between criteria, with a view 
to eliminating unnecessary clauses, integrating criteria, unifying terms and producing a new structure for the AACR2. Molto and Svenonius ${ }^{58}$ devised a prototype for an electronic interface to explore procedures for reforming the AACR2, and found that the main problem lay in the structure of the text.

The present findings with regard to the loss of author access points for mentions of up to three and more than three authors are evidence of the consequences of the rule of three. The data indicate that this rule is applied zealously for coauthors and collaborators in works with more than three authors regardless of the source location where the names appear. The absolute numbers are revealing: the records I samples contained 89 actual entries out of a potential total of 1548 (i.e., $94.26 \%$ of the access points were lost). In contrast, for non-creative authors the results suggest that the rule of three is applied less systematically and less uniformly. This is further evidence that some rules for choosing author access points are used inconsistently, as suggested above for the choice of added entries. The $62.6 \%$ loss of potential access points for translators in works that mention up to three authors may reflect the fact that the translator's name often appears on the copyright page (other sources).

\section{CONCLUSIONS}

The rules for choosing access points are in urgent need of revision to adapt them to online cataloguing. As the present findings show, the revision should aim to simplify and clarify criteria, and to remove the limitations of the current precepts.

To make the rules more functional, I suggest that the principle of the main entry and the hierarchy of decreasingly important access points be replaced with a system to categorize types of authorship. The types of authors in each category could be designated as obligatory or optional from evidence-based criteria, including, possibly, a quantification of the presence of each type of author in the work and the importance of each author's contribution. Another possible criterion could be the usefulness of each author for information retrieval by catalog users. This would open novel lines of research.

The set of categories of authors I used had the disadvantage of requiring each author and type of authorship to be correctly identified in order to assign authors to one category or the other. The use of function indicators or their equivalents may be a valid (although not infallible) procedure, particularly for the automatic determination of access points.

The present findings suggest that overcoming the limitations of the current rules will help to optimize cataloguing processes by increasing the number of author entries. If additional author access points are used for information re- 
trieval, the catalog will become more accessible via creative authors' entries; however, this means that the table of contents should be consulted. The consequent increase in the number of entries would thus improve the retrievability of only a small group of publications, i.e., collections, congress proceedings and collaborative works. The table of contents must therefore be used with caution, although its exploitation would be a major contribution toward building an analytical catalog.

However, a second look at the data suggested that the problem went deeper than the question of using or ignoring the table of contents as a source of authors. The number of access points lost as a result of ignoring the table of contents was worrying in itself. Nonetheless, the ambiguities in the text of the current cataloguing rules, or the lack of rules to deal with certain specific cases, lead to inconsistencies in the choice of access points for non-creative authors as catalog entries.

The loss of access points from the title page, a devastating consequence of the rule of three, is evidence in support of calls to do away with this rule, at least for creative authors. Ignoring the rule of three would reduce the number of losses for coauthors and collaborators located in this source. The rule of three not only compromises the identification and retrieval of all works related with a given author regardless of the nature of his or her contribution, but also violates the authors' right to appear in the indexes. This right is now being affirmed by science authors whose production is evaluated on the basis of the appearance of their name in bibliographic databases. ${ }^{59,60}$ Paradoxically, the rule of three makes it impossible to retrieve a work with four authors unless the title of the work or the name of the first author is known-even though the same work could be retrieved on the basis of the name of the author of the prologue if it appeared on the title page. Current catalogs do not provide enough entry points to solve this type of retrieval problem. To accurately judge the real importance of the problems detected for non-creative authors, it will be necessary to determine how often they are used for information retrieval, at least in standard searches. Nonetheless, the present findings suggest that better rules for choosing the entries for these authors would improve the consistency of the catalog, and would moreover make it possible to link each author to all the works he or she participated in regardless of the type of authorship role.

Received: March, 2001

Revised: May, 2001

Accepted: May, 2001 


\section{REFERENCES}

1. Lancaster, F.W., and Smith, L.C. Compatibility Issues Affecting Information Systems and Services (PGI-83/WS/23) (Paris: Unesco, 1983).

2. Bell, J., and Speer, S. "Bibliographic verification for interlibrary loan: Is it necessary?" College Research Libraries 49 (1988): 494-500.

3. O'Neill, E.T., and Vizine-Goetz, D. "Quality control in online database" Annual Review for Information Science and Technology 23 (1988):125-47.

4. Jacso, P. "Content evaluation of databases" Annual Review of Information Science and Technology 32 (1997):231-67.

5. Langballe, A.M.H. "Brief Cataloguing in Card and Online Catalogues" International Cataloguing \& Bibliographic Control 20, 3 (1991): 28-31.

6. Lambrecht, J.H. Minimal Level Cataloguing by National Bibliographic Agencies (Münich: Saur, 1992) (UBCIM Publication; N.S., Vol. 8).

7. Oddy, P. "Authority control in the local, national an international environment" In Standards for the international exchange of bibliographic information (London: Library Association Publishing, 1991); p. 66-72.

8. Lin, J.C. "Rule of three: A case of discrimination against certain authors caused by the Cataloguing rules" Cataloging \& Classification Quarterly 5, 4 (1985):53-65.

9. Winke, R.C. "Discarding the main entry in an online Cataloguing environment" Cataloging \& Classification Quarterly 16 (1993):53-70.

10. Seal, A., Bryant, P., and Hall, C. Full and short entry catalogues: Library needs and uses (Bath: University Centre for Catalogue Research, 1982).

11. Wilson, P. "The catalog as access mechanism: Background and concepts" Library Resources \& Technical Services 27 (1983):4-17.

12. Shoham, S., and Lazinger, S.S. "The no-main-entry principle and the automated catalog" Cataloging \& Classification Quarterly 12, 3/4 (1991):51-67.

13. Winke, R.C. "Discarding the main entry in an online Cataloguing environment" p. $53-70$.

14. Bierbaum, E.G. "A modest proposal. No more main entry" American Libraries (January 1994):81-84.

15. Abrera, J., Shaw, D. "Frequency of use of cataloguing rules in a practice collection" Library Resources \& Technical Services 36 (1991):149-61.

16. Meador, R., and Wittig, G.R. "AACR2 rules used in assigning access points for books in two subjects: Implication for automatic cataloguing expert systems" Library Resources \& Technical Services 35 (1991):135-40.

17. Svenonius, E., Baughman, B., and Molto, M. "Title page sanctity? The distribution of access points in a sample of English language monographs" Cataloging \& Classification Quarterly 6: (Spring 1986):3-21.

18. Jones, E.A.. "Consistency in choice and form of main entry: A comparison of Library Congress and British Library monograph Cataloguing" Library Resources and Technical Services 36 (1991):209-23.

19. Svenonius, E., and Molto, M. "Automatic derivation of name access points in Cataloguing” Journal of the American Society for Information Science 41 (1990):254-63.

20. Molto, M., and Svenonius, E. "Automatic recognition of title page names" Information Processing \& Management 27 (1991):83-95. 
21. Hjerppe, R., and Olander, B. "Cataloguing and expert systems: AACR2 as a knowledge base" Journal of the American Society for Information Science 40 (1989): 27-44.

22. Evans, D. et al. "Using the new AACR2: An expert systems approach to choice of access points" Library-Quarterly 65 (1995):140-1.

23. CC:DA. Committee on Cataloguing: Description \& Access. Building International Descriptive Cataloguing Standards: The role of the American Library Association's Committee on Cataloguing: Description \& Access [on line] <http://www.ala.org/ alcts/organization/ccs/ccda/ccda.html> [consultation: 21/01/99].

24. JSC. Joint Steering Committee for Revision of Anglo-American Cataloguing Rules. The logical structure of the Anglo-American Cataloguing Rules-Part 1 [on line] $<$ <ttp://www.nlc-bnc.ca/jsc/aacrdel.html> [consulted 25/01/99].

25. ICPF of AACR International Conference on the Principles and Future Development of AACR, Toronto, October 23-25, 1997 [on line] http://www.nlc-bnc. ca/jsc/confpap.htm [consulted 21/01/99].

26. Fattahi, R. AACR2 and Catalogue Production Technology: The Relevance of Cataloguing Principles to the Online Environment. International Conference on the Principles and Future Development of AACR, Toronto, October 23-25, 1997 [on line] http://www.nlc-bnc.ca/jsc/confpap.htm [consulted 21/01/99].

27. Delsey, T. Modeling the logic of AACR. International Conference on the Principles and Future Development of AACR, Toronto, October 23-25, 1997 [on line] http://www.nlc-bnc.ca/jsc/confpap.htm [consulted 21/01/99].

28. Sandberg-Fox, A., and Byrum, J.D. "From ISBD (CF) to ISBD (ER): Process, policy and provision" Library Resources \& Technical Services 42, 2 (1998): 89-101.

29. CC:DA. Committee on Cataloging: Description \& Access. Task Force Harmonization of ISBD(ER) and AACR2 [on line] <http://www.ala.org/alcts/organization/ ccs/ccda/ccda.html> [consulted: 21/10/99].

30. Hagler, R. Access Points for Works. International Conference on the Principles and Future Development of AACR, Toronto, October 23-25, 1997 [on line] http://www.nlc-bnc.ca/jsc/confpap.htm [consulted 21/01/99].

31. CC:DA. Logical Structure of the Anglo-American Cataloguing Rules [on line] $<$ http://www.ala.org/alcts/organization/ccs/ccda/ccda.html> [consulted 21/01/99].

32. AACR2. Anglo-American Cataloguing Rules, 2nd ed., 1998 Revision. (Ottawa; London; Chicago: Canadian Library Association; Library Association Publishing; American Library Association, 1998).

33. AACR2-e. Anglo-American Cataloguing Rules, 2nd ed. 1998 Revision [CD-ROM]. Published jointly by the American Library Association, the Canadian Library Association, and the Library Association. [reference source: <http://www.ala.org/ market/books/technical.html>].

34. RCE. Reglas de Catalogación Españolas (Madrid: Dirección General del Libro, Archivos y Bibliotecas, 1995).

35. AACR2R. Anglo-American Cataloguing Rules, 2nd ed., 1988 Revision (Chicago: American Library Association, 1988).

36. Bierbaum, E.G. "A modest proposal. No more main entry" p. 81-84.

37. Shoham, S., and Lazinger, S.S. "The no-main-entry principle and the automated catalog" p. 51-67. 
38. Madison, O.M.A. "The role of the name main-entry heading in the online environment" The Serials Librarian 22 (1992):371-91.

39. Boll, J. "The future of AACR2" Cataloging \& Classification Quarterly 12 (1990):3-34.

40. Svenonius, E., Baughman, B., and Molto, M., 1986. "Title page sanctity? . . "” p. $3-21$.

41. Brunt, R.M. "The code and the catalogue: A return to compatibility" Library Review 41 (1992):21-32.

42. Lin, J.C. 1985. "Rule of three: A case ..." p. 53-65.

43. Schulman, J.L. "New author policy for NLM indexes and database" NLM Technical Bulletin 287 (1995):17.

44. ICMJE. "International Committee of Medical Journal Editors. Uniform Requirements for Manuscripts Submitted to Biomedical Journals" Annals of Internal Medicine 126 (1997):36-47.

45. Garfield, E. "All Sorts of Authorship" Nature 389 (1997):777.

46. Svenonius, E. ed. The conceptual foundation of descriptive cataloguing. (San Diego: Academic Press, 1989).

47. Svenonius, E., Baughman, B., and Molto, M., 1986. "Title page sanctity? . . "” p. 3-21.

48. Molto, M., and Svenonius, E. "Automatic recognition of title page names" Information Processing \& Management 27 (1991):83-95.

49. Ruiz-Perez, R. "Choice of author access points for online catalogs of monographs in Spanish" Cataloging \& Classification Quarterly 26, 4(1998):5-32.

50. Ruiz-Perez, R. "Choice of author access points ..." p. 5-32.

51. Winke, R.C. "Discarding the main entry in an online Cataloguing environment" p. $53-70$.

52. Svenonius, E., Baughman, B., and Molto, M., 1986. "Title page sanctity? . . "” p. 3-21.

53. Cockshutt, M.E., Cook, C., and Schabas, A.H. "Decision logic for AngloAmerican Cataloguing Rules, Chapter 21 Choice of access points" Library Resources \& Technical Services 27 (1993):371-90.

54. Meador, R., and Wittig, G.R. "AACR2 rules used in assigning access points ..." p. $135-40$.

55. Abrera, J., and Shaw, D. 1991. "Frequency of use of cataloguing rules in a practice collection" p. 149-61.

56. Winke, R.C. "Discarding the main entry in an online cataloguing environment" p. $53-70$.

57. Taniguchi, S. "A system for analyzing Cataloguing rules: A feasibility study" Journal of the American Society for Information Science 47 (1996):338-56.

58. Molto, M., and Svenonius, E. “An Electronic Interface to AACR2” Cataloging \& Classification Quarterly 26 (1998):3-24.

59. Epstein, R.J. "Six authors in search of a citation: Villains or victims of the Vancouver convention?” British Medical Journal 306 (1993): 765-67.

60. Horton, R., and Smith, R. "Signing up for authorship" Lancet 347 (1996): 780. 


\section{APPENDIX 1. Taxonomy of Responsibility Functions in Modern Monographs (Spanish Designations and English and French Equivalents ${ }^{1}$ )}

\begin{tabular}{|c|c|c|}
\hline Spanish & English (Code) & French \\
\hline $\begin{array}{l}\text { Autor } \\
\text { Personal or corporate } \\
\text { body authorship } \\
\text { Coautor } \\
\text { Colaborador } \\
\text { Adaptador } \\
\text { Actualizador, Revisor } \\
\text { Editor-Compilador } \\
\text { Editor-Preparador } \\
\text { Director-Coordinador } \\
\\
\text { Continuador }{ }^{2} \\
\text { Compendiador }{ }^{3} \\
\text { Comentador } \\
\text { Redactor } \\
\text { Relator, Relatador } \\
\text { Colaborador en materias } \\
\text { auxiliares } \\
\text { Prologuista } \\
\text { Ilustrador } \\
\text { Traductor } \\
\text { Editor comercial }\end{array}$ & $\begin{array}{l}\text { Author, Writer, Emanator (Auth.) } \\
\text { Joint author, Coauthor (Coaut.) } \\
\text { Contributing author (Coll.) } \\
\text { Collaborating author } \\
\text { Collaborator } \\
\text { Adapter (Adp.) } \\
\text { Annotator; Reviser (Annot.) } \\
\text { Maintainer; Revised version } \\
\text { Editor, Compilator (Edt-com.) } \\
\text { Compiler } \\
\text { Director-Coordinator (Drt-coord.) } \\
\text { Editor } \\
\text { "Continuer" (Cont.) } \\
\text { "Abstractor" (Comp.) } \\
\text { Commentator, Annotator (Comm.) } \\
\text { Redactor; Writer (Rd.) } \\
\text { Narrator (Nrt.) } \\
\text { Writer of accompanying material (Wam) } \\
\text { Author of the Preface, Prologue or } \\
\text { Foreword (Pr.) } \\
\text { Illustrator, Photographer (III.) } \\
\text { Translator, Transcriber (Trl.) } \\
\text { Publisher (Pbl.) }\end{array}$ & $\begin{array}{l}\text { Auteur proprement dits } \\
\text { Auteur collectivité } \\
\text { Coauteur } \\
\text { Collaborateur } \\
\text { Contribution, Contribuant } \\
\text { Avec la participation } \\
\text { Adaptateur } \\
\text { Auteur de mise à jour } \\
\text { Éditeur } \\
\text { Éditeur, Compilateur } \\
\text { Éditeur scientifique } \\
\text { Directeur; Directeur de } \\
\text { publication } \\
\text { Coordinateur o } \\
\text { Coordonnateur } \\
\text { Continuateur } \\
\text { Commentateur; Annoté } \\
\text { Glose par } \\
\text { Rédacteur } \\
\text { Narrateur, Relateur } \\
\text { Collaborateur auxiliaire, } \\
\text { complément } \\
\text { Préfacier; Avant-propos, } \\
\text { Présente } \\
\text { Illustrateur; Iconographie } \\
\text { Traducteur } \\
\text { Editeur commerciaux }\end{array}$ \\
\hline
\end{tabular}

\section{Sources:}

- Reglas de catalogación. Ed. refundida y rev. Madrid: Dirección General del Libro, Archivos y Bibliotecas, 1995

- Anglo-American Cataloguing Rules, 2nd ed., 1988 Rev. (Chicago: American Library Association, 1988)

- USMARC Code List for Relator, Sources, Description Conventions, Prepared by Network Development and MARC Standards Office. Washington: Library of Congress, Cataloging Distribution Service, 1990

- AFNOR, Z 44-059: Documentation: Catalogage: Choix des Accès à la Description Bibliographique (Paris: AFNOR, 1987), p. 130

- J. Martínez de Sousa, Diccionario de Bibliología y Ciencias Afines. (Salamanca: Fundación Germán Sánchez Ruipérez, 1993)

2. No standardized equivalents in English found

3. No standardized equivalents in English or French found

4. This is not described as a separate function in any set of cataloging rules, and is termed here colaborador en ... to distinguish it from the creative author collaborator. This function involves contributions that are not of fundamental importance for the content of the work, and without which the work could exist on its own, although accompanying material often facilitates the use of the basic work. A variety of terms are used to designate this type of function, to reflect the variety of materials in both the front matter and the back matter that can accompany a work (e.g., appendices, indices, supplements, tables and bibliographies). 